\title{
Customer Value Proposition for E-Commerce: A Case Study Approach
}

\author{
Nurhizam Safie Mohd Satar ${ }^{1}$, Omkar Dastane $^{2}$, Muhamad Yusnorizam Ma'arif ${ }^{3}$ \\ Research Center for Software Technology and Management (SOFTAM) \\ Faculty of Information Science and Technology \\ National University of Malaysia (UKM), 43600 Bangi, Malaysia ${ }^{1,3}$ \\ School of Accounting \& Business Management, FTMS Global Malaysia \\ Block 3420, Persiaran Semarak Api, Cyber 4, 63000 Cyberjaya, Malaysia ${ }^{2}$
}

\begin{abstract}
E-Commerce tools have become a human need everywhere and important not only to customers but to industry players. The intention to use E-Commerce tools among practitioners, especially in the Malaysian retail sector is not comprehensive as there are still many businesses choosing to use expensive traditional marketing. The research applies academic models and frameworks to the real life situation to develop a value proposition in the practical world by considering 11Street as the company under study and comparing it with Lazada as a leading competitor in the market. The objectives include identification of customers' perception of a value for ECommerce Businesses, followed by critical evaluation of existing value proposition of 11Street with Lazada to identify gap and finally to propose a new value proposition for 11street. This paper first identifies customer perceived value of E-Commerce followed by critical review of existing value proposition of 11Street and then comparing and contrasting with the leading player Lazada. By the end of this research, a new consumer value proposition proposal for 11Street proposed for consideration in matching with the Malaysian consumers' value criteria.
\end{abstract}

Keywords-Online consumer; perceived value; e-commerce; value proposition

\section{INTRODUCTION}

Electronic Commerce or e-commerce defined as all aspects of business and market processes enabled by the Internet. Ecommerce is rapidly becoming a viable means of conducting business, as evidenced by the tremendous amounts of money spent online. E-commerce is a web-based platform that is gaining popularity and becoming increasingly important, enabling various types of economic transactions to be conducted and facilitated on the web. E-commerce has grown into a dynamic set of technologies, through which applications and businesses are radically shifted to the digital form and delivered through the internet [5]. E-commerce industry in Malaysia expected to reach USD 3.2 Billion by 2019 and grow at a CAGR of $19.5 \%$ from 2014 to 2019 . In which online travel is the largest segment of E-commerce in Malaysia, followed by retails and deal sites [6]. Some of the famous online retailers in Malaysia are Agoda, Airasia, Zalora, Lazada, Mudah.my and Lelong.com.my. According to [7], Malaysian at large ranked Lazada.com.my, Mudah.my and 11Street.my as the top 3 ecommerce site in the country.

Furthermore, Malaysians particularly the millennial generation tend to purchase apparel, electronic devices, sports equipment, books and health related items. In term of mode of payment, Malaysian would probably use both debit and credit cards or to pay cash on delivery and for the good delivery, $90 \%$ of Malaysian would rank product delivery by a postal courier as the most reliable and trusted mode of delivery.

Rocket Internet has founded that Lazada Group, an ecommerce company based in South East Asia and later in 2016, Alibaba Group acquired it. Since 2014, the Lazada Group had its operation in the following countries: Indonesia, Malaysia, Philippines, Singapore, Thailand, and Vietnam. In a customer behavioral perspective, customer satisfaction often viewed as a function of transaction-specific satisfaction and multiple transaction-specific's satisfaction. This perspective may be viewed as decisions made by customers about the service quality, product quality and price [8]. The values that the customer observe shows their attitude towards product selection, especially when the product is intangible. Lazada Group had raised around US\$647 million from Temasik Holdings, Tesco, Summit Partners, JP Morgan Chase, Investment AB Kinnevik and Rocket Internet. In March 2012, it sites was launched with a business model of selling inventory to customers from its own warehouses. In 2013, it added a marketplace model, which allowed third-party retailers to sell their products via Lazada's site; later the marketplace accounted for $65 \%$ of its sales by the end of 2014. Customer engagement in the business is a new term in marketing literature, which has received considerable attention from researchers to better reflected the strength of a relationship established between parties in a relationship. Scholars argued that customer engagement has a greater explanatory power to indicate the relationship strength as it does not only encompass the emotional, cognitive and behavioral components, but also exist because of a two-way exchange between partners [9].

11 street is one of the huge e-commerce companies established by SK Planet in South Korea back in 2014. Originally, 11street was a pioneering e-commerce company in South Korea operates and manages by SK Planet Co., Ltd. 11 street expanded its operations to Malaysia with Celcom as the joint venture partner of SK Planet. The 11street Malaysia is currently operating from their main office located at Kuala Lumpur Sentral since January 2015. The objectives of the present study are described as follows: (1) To identify a suitable model of customer perceived values (CPV) for both Lazada.com.my and 11street.my. (2) To compare and contrast 
the organizational value proposition between Lazada.com.my and 11 streeet.my. (3) To propose new value proposition for 11street.my. (4) To implement the proposal of the new value proposition of 11street.my. In [28], authors have found that customer outcomes of perceived customer orientation and service quality have a critical role in building a long-term relationship between the customer and the service provider.

In order to fulfill the objectives of the present study, we drew on theories analyzed and discussed in previous studies in the area of customer perceived values (CPV) and built upon research instruments proposed and developed by researchers in relevant studies.

\section{RESEARCH METHOD}

To achieve the objectives, we have employed case study approach method by selecting 11 street.com.my as ECommerce company under study and leading competitor as Lazada.com.my. We follow reporting style demonstrated by [10] as it being suitable, critical and concrete in nature covering all aspects of case development. To achieve first objective of identification of customer perceived value dimensions, we have applied model as in [1]. By collecting secondary qualitative data from peer reviewed published journal articles, identification of CPV elements and respective dimensions is carried out. We have implemented value proposition framework developed by [2], [3] and recommended by [10] to compare and contrast value proposition of both companies under consideration. Finally, framework as in [4] is used to develop a framework for new value proposition. We then proposed a systematic structure that E-commerce businesses can utilize to benchmark against, in order to develop value proposition for their customers.

\section{LITERATURE REVIEW AND CASE ANALYSIS}

\section{A. Customer Perceived Value for E-Commerce}

As commonly defined CPV is "the consumer overall calculation of the usefulness of a product based on perceptions of what is predicted and what is delivered" [11]. Customer perceived value is the prime driver of competitive advantage in the Internet shopping environment [1]. Ever since the year of 2000, Internet users researching a product or purchasing online has multiply [12]. Reference [1] has identified two types of online shopping perceived value namely the utilitarian value and experiential (hedonic) value. Utilitarian value is relevant to rational and goal-directed shopping behaviors and is attainable from deliberate and efficient product acquisition, while experiential value is more subjective and personal and arises from fun and the playfulness of the shopping experience rather than fulfillment of the shopping task [13]; [14]; [1]. Therefore, model as in [1] is suitable for this paper because it clarifies the motives why consumer buy a product/service to be beneficially valued and sacrificially valued although it cost a high fees or there is sacrifices to be made similar to pay for a higher shipping/delivery cost. Table 1 shows those values receive to shop online with the subsequent discussion emphasizing on the relevant topics identified.

As per [1], assessment of "functional benefits and sacrifices" is a utilitarian value linked with an online shopping experience. Utilitarian value is particularly applicable to goal- unique buying tasks wherein customers searching to assess ability purchases, based totally on criteria such as services or products price and available features, or truly attain their goal efficaciously while minimizing irritation [15]. The utmost utilitarian value is the price whereby customers are able to enjoy great discount purchasing online and saves transportation expenses [1], but not all products are available online. Sacrifices made to pay more on the shipping/delivery cost. Judgments pertaining price-value relationships, provider great, and convenience (aid conservation and ease of transaction) are additives of utilitarian value [1].

Next utilitarian value of convenience is the ability to shop online. This encourages shopping efficiency as it delimits frustrations related to shopping at physical stores such as transportation issues and looking for items from different stores in comparison shopping. With online stores which are open $24 / 7$, consumers with online access have more flexibility to shop with the on the go mobile application and time needed to do so [16]. The capacity to fit a customer's schedule is utmost necessary as research has identified timesaving as a leading motivation in online shopping [12]; [1]. However when comes to receiving the products, it may take time as items ordered will not be received on the spot. In addition, since purchasing done online, there is possibility of bad network, mobile data limitations and the device used which has limited storage to download brochures thus creates frustrations among the consumers. Another value is the selection. It is also crucial for the shop website to provide information about a service and product to assist in purchase consideration [1]. Ability to view the visual and features of the product gives convenience to the customers to purchase the product. As this is restricted to viewing the products, customers may not be aware of the quality of products as its lacking the touch and feel of the particular online product. There are possibilities whereby the seller or the company advertised those products is unknown or not recognized by public. This can lead to the consumers being cheated during or after purchase is made. Service quality is another aspect of utilitarian value, which considers the services given while shopping also after the purchase made [17]; [1]; [18]. Its facility such as the product comparison tool to assist customers to compare other products also with added assistance from the helpdesk gives convenience and ease during sales and after sales. Reflection of a customer's gratitude towards e-retailer's ability to execute on its promises known as perceived service quality [18]. However not all eretailers provides e-support and there is no selection to bargain for price reduction.

Experiential value is an overall measurement of benefits and sacrifices taken from the experience of online shopping which includes entertainment, escapism, interactivity as well as visual appeal [19]. The components boost customer's overall shopping experience [20]; [1]. Previous studies show that online customers visit websites for entertainment and fun not solely for information [21]; [1]. They gain pleasure from finding great deal and experience social pleasure when interacting with others online. When online consumers believe their purchase in an e-retailer to be fun and enjoyable, they get experiential benefits resulting from shopping activities [13]. However, over time they will lose the tactile experience. 
E-retailers able to develop visual appeal for online consumers by using aesthetic appeal and design [1] which such visual appeal can give immediate pleasure and excitement during browsing [18]. This can also lead to deceptive pictures whereby the view of a product in the website is different compare to when it's purchased. The thought of not being stuck in traffic jam and looking for parking when visiting a physical store gives the feeling of escapism but customers have to rely on the availability of the internet to browse. In addition, due to some device constraints, customers will not be able perform online transaction and some not able to get the full view of the product due to screen resolution of the mobile.

Interactivity in which customers interact intensively with computers when shopping online builds electronic trust through the navigation and information presented online [22]. Also interaction with other customers online, gives a social dimension of experiential value as in [15] by which also facilitating the exchange of information through chat rooms, product reviews and forums [1]. Sacrifices in this aspect, possibility of other customers sharing incorrect information in the chat rooms and misled the buyer whether to purchase or not to purchase the product or services.

\section{B. Value Proposition of Both e-Commerce Companies, Lazada.com.my and 11street.my are Projected in the Following Table}

From the Table 1, the value proposition of Lazada.com.my is accessibility, affordability and convenience which mean at the moment, Lazada's supply chain and its 10,000 third-party sellers offer products below the stores prices, and as up to 5.5 million products sold at the e-commerce site are not even available in any physical stores. Accessibility means customer can do an online shopping anywhere and at any time through Internet connectivity. According to [23], Lazada claim that the company as a rural company, which served $80 \%$ needs of customers outside Klang Valley. Lazada covering an entire state of Peninsular Malaysia and most likely will expand to Sabah and Sarawak.

Table 2 explained about 4P's introduces to marketing education as in [24]. Jerome Mc Carthy in 1960 [24] provided a framework by means of the marketing mix: the 4P's. The 4P's include Product, Price, Place and Promotion. The 4P's also known as the basic marketing mix. The marketing mix is a crucial tool to help understand what the product or service can offer and how to plan for a successful product offering.

TABLE I. COMPARISON OF VALUE PROPOSITIONS OF LAZADA.COM.MY AND 11STREeT.MY

\begin{tabular}{|c|c|c|c|c|}
\hline Company & Target Customer & Benefits & Price & Value Preposition \\
\hline Lazada & $\begin{array}{l}\text { Social Media Users } \\
\text { Geographic Markets } \\
\text { (facebook, 2017) }\end{array}$ & $\begin{array}{l}\text {-Wide range of known and } \\
\text { unknown products } \\
\text {-Fast delivery } \\
\text {-Cash on delivery } \\
\text {-Multiple options with many } \\
\text { vendors } \\
\text { (Carazon.K, 2012) } \\
\text {-Blogger context }\end{array}$ & $\begin{array}{l}\text { Moderate } \\
\text { Low (Carazon.K, 2012) }\end{array}$ & $\begin{array}{l}\text {-Cash on delivery is accepted. } \\
\text {-More convenient } \\
\text {-Well established online shop }\end{array}$ \\
\hline 11Street & $\begin{array}{l}\text { Target to young most e- } \\
\text { commerce users } \\
\text { (intellingence, 2017) }\end{array}$ & $\begin{array}{l}\text {-Present promotions/ offers } \\
\text { (11street, 2017) } \\
\text {-Supplies coupons based on e- } \\
\text { shopping location } \\
\text {-Buyer grades (new, VIP, VVIP) } \\
\text { (11Street, 2017) } \\
\text {-Firefly Airlines Partnership }\end{array}$ & Low & $\begin{array}{l}\text {-Convenient } \\
\text {-User friendly webpage } \\
\text {-Attractive offers } \\
\text {-Low cost coupons offered } \\
\text {-Longer period valid coupons } \\
\text { Trust \& Reliability, } \\
\text { Price Competitiveness, } \\
\text { Convenience, Style \& Variety }\end{array}$ \\
\hline
\end{tabular}

TABLE II. The 4P's INTROdUCED To MARKETING EdUCATION By E. JEROME MCCARTHY IN 1960 (AS IN [24])

\begin{tabular}{|l|l|l|}
\hline 4 P'S & Long Term & Short tem \\
\hline Product & $\begin{array}{l}\text { 11street to develop specific products such as DELL laptop computer or Polo } \\
\text { perfumes }\end{array}$ & $\begin{array}{l}\text { To start setting the existing products online in order to } \\
\text { accumulate the right knowledge and experience as to } \\
\text { develop products for the online }\end{array}$ \\
\hline Price & $\begin{array}{l}\text { 11street to develop pricing strategy which should considers the change of the } \\
\text { cost structure }\end{array}$ & $\begin{array}{l}\text { 1) Bundling strategy - to create more value-added at the } \\
\text { same price } \\
\text { 2) To differentiate the packaging of the products }\end{array}$ \\
\hline Place & $\begin{array}{l}\text { 1) To secure online channels which include the brand characteristics } \\
\text { 2) To adjust channel strategy along with the evolvement of online retail } \\
\text { market }\end{array}$ & $\begin{array}{l}\text { To leverage on online market place rather than developing } \\
\text { its own channel at the beginning }\end{array}$ \\
\hline Promotion & $\begin{array}{l}\text { 1) To secure personal marketing capability such as digital marketing and } \\
\text { marketing automation. } \\
\text { 2) To secure integrated marketing capability such as through email, website, } \\
\text { social media and SMS }\end{array}$ & $\begin{array}{l}\text { 1) Leverage an online marketplace capability as to promote } \\
\text { products online }\end{array}$ \\
\hline
\end{tabular}


Table 2 indicates about the long-term and short-term marketing planning by 11 Street according to 4P's theory. The more affordable the products are sell will lead to more affordable for customers to cut across all level of household income. The more convenience the product sell, the customers can shop anywhere and at any point of time as long as there is Internet connectivity. Furthermore, Lazada logistics and warehouse systems are very efficient to courier and distribute the products to the customers nationwide. As for the 11 street.my, its value proposition is "Find what you love at 11street". The proposition, which means, customers can purchase any product they like ranging from baby products, Korean products and home decorations as long as there is Internet connectivity.

\section{RESULTS AND FINDING}

\section{A. New Value Proposition that will Match the Value Criteria of the Customers}

Truly, No. 1 shopping experience is the new value proposition of 11 street as they have some additional services in which Lazada do not have. Pricing also plays a huge part in ecommerce and how much customers willing to pay. Truly enough, it is not true that the lower the value, the more likely customers are to make a purchase. Among the value proposition which 11 street.my should embrace is the Omnichannel marketing strategy. Omni-channel marketing strategy defined as the multi-channel sales approach, which provides the customer with an integrated shopping experience. The customer can be shopping online from a desktop or mobile device, via phone, or in an offline store of 11street in their premise in KL Sentral, Kuala Lumpur, and the customers experience shall be seamless.

\section{B. New Value Proposition Contributing to Competitive Advantage}

A value proposition is an explicit promise made by a company to its customers that it will deliver a particular bundle of value creating benefits. So while trying to create a new value proposition for 11 street one should increase the customer benefits or enhance the existing services for better shopping experience. In this case, the long checkout procedure considered as one of the main reasons for cart abandonment, which have greater rate up to 70 percent. According to a number of studies, this point exactly have been solved by Amazon.com since 1999 when they created an enhanced value proposition for Amazon's end consumer is the "One-Click" patent filed in 1999 and featured on its online store. This feature allow customers to make online purchases with a single click, they do not have to re-submit the lengthy, and cumbersome payment and shipping information if the user has previously provided it (return customers). The One-Click patent creates a very strong position for Amazon in the market. Hence, it allowed Amazon to show consumers the logical reason to use their data and the permission to charge them on an incremental basis. Amazon secured the patent in 1999, and it represented as innovative idea of hassle-free online shopping. In September 12, 2017, marked the end of an era as the patent expired for Amazon's "One-Click" button for ordering. However, other retailers can now adopt one-click ordering without facing the threat of lawsuits or having to pay to license it from Amazon. One-Click purchasing is getting more and more usual within the websites dealing with online shopping. The recent years have gone through a rapid growth of ecommerce and because of that, the distribution of goods to consumers has reshaped. Value has jointly created by providers and customers through interactions and determined by customers in their consumption process [25]. In [26], the author explained a value (co) creation mechanism consists of provider sphere, joint sphere, and customer sphere. While provider sphere, like companies resources (goods, facilities, activities, or personnel) and processes for value propositions, serving as a creator of expected value-in-use. Moreover, the customer sphere, customers lead the value by their own resources (e.g., time, money, knowledge, motivations, skills, or actions) with the company's value proposition [27]; [26].

\section{CONCLUSION}

In conclusion, this research has successfully identified the value proposition for 11 Street.my as well as evaluated how 11 street.my to meets consumers perceived value and finally how the value proposition can be modified to ensure success of the business in the future. However, this research paper only represents a brief of the current value related with e-commerce business of 11 street. Therefore, the value proposition should be further investigated and frequently reviewed to remain competitiveness of customer needs.

Equally important, 11st street.my should obtain continuous responses from the staff, incorporating their mind into the new process of change to ensure the internal processes are smoothly running according to the plan. By ensuring that 11st Street strictly follows these recommendations and adopts the recommended value proposition and implementation strategy, 11 street.my should stimulate a competitive advantage, which not only will help mitigate the competitive threat of Lazada.my, yet shall escalate the 11street.my brand image as the leader in e-commerce sector.

Currently, 11Street.my has met these customers' values and how its value proposition can be altered to ensure future success of the e-commerce business in Malaysia. In this competitive era of e-commerce, customer perceived values is important and no company can deny significant of customer perceived values. The head-to-head summary of customer perceived values on both e-commerce providers also has shown that e-commerce provider must be focus and align their product and services to be customer focus.

\section{LIMITATION OF THE STUDY}

This study has a limitation like other research. In order to strengthen this study, future research should consider the following suggestions: First, several organizational and personal characteristics should be further explored to show the customer perspective and characteristic to influence the proposed value proposition implementation plan. Second, a strong research designs like longitudinal studies should be utilized to collect data and describe the patterns of change to see the causal relationships amongst variables of interest. Third, to understand the effect of service quality on customer perception and behavior, by conducting a survey to the various respondents in a specific area of the study. 


\section{REFERENCES}

[1] Lee E. J. and Overby J. W. (2004). Creating Value for Online Shoppers: Implications for Satisfaction and Loyalty. Volume 17, 2004.

[2] Piercy N. F. (2009). Market-Led Strategic Change: Transforming the Process of Going to Market 4th Edition. Oxford, Elsevier.

[3] Anderson J., Narus J., \& Van Rossum W. (2006). Customer value propositions in business markets. Harvard Business Review. May 2006, page $90-99$.

[4] Osterwalder A., Pigneur Y., Bernarda G. and Smith A. (2014). Value proposition design: How to Create Products and Services Customers Want (Strategyzer). New Jersey: Wiley. October 20th, 2014. ISBN-13: 978-1118968055.

[5] Elias, N. F., Mohamed, H. \& Arridha, R. R. 2015. A study on the factors affecting customer satisfaction in online airline services. International Journal of Business Information Systems 20(3): 274. doi:10.1504/ijbis.2015.072249

[6] KEN Research (2014). Malaysia E-commerce Industry Outlook to 2019 - Driven by Internet Penetration and Mobile Access Devices. Retrieved on 15th April, 2018. https://www.kenresearch.com/technology-andtelecom/it-and-ites/malaysia-e-commerce-market-research-report/606105.html

[7] Fawzi et. al. (2018). E-Commerce Adoption and an Analysis of the popular E-Commerce Business Sites in Malaysia. Journal of Internet Banking and Commerce, April 2018, vol. 23, no. 1

[8] Ismail, A., Rose, I. R., Tudin, R. \& Mat Dawi, N. 2017. Relationship between Service Quality and Behavioral Intentions: The Mediating Effect of Customer Satisfaction. Etikonomi 16(2): 125-144. doi:10.15408/etk.v16i2.5537

[9] Zainol, Z., Omar, N. A., Osman, J. \& Habidin, N. F. 2015. The Effect of Customer-Brand Relationship Investments on Customer Engagement: An Imperative for Sustained Competitiveness. Jurnal Pengurusan 44: 117-127. doi:10.1080/15332667.2016.1209051

[10] Wong, S. W., Dastane, O., Safie, N., Ma'arif, M.Y. (2019). What Wechat can learn from Whatsapp? Customer Value Proposition Development for Mobile Social Networking (MSN) Apps: A Case Study Approach. E-ISSN 1817-3195, Vol. 97 Issue 04. Journal of Theoretical and Applied Information Technology, 97(4)

[11] Zeithaml, V. A. (1988). Consumer Perceptions of Price, Quality, and Value: A Means-End Model and Synthesis of Evidence. Journal of Marketing, 52(3), 2-22. https://doi.org/10.2307/1251446

[12] Horrigan, J.A., 2008. Online shopping. Pew Internet \& American Life Project Report, 36, pp.1-24.

[13] Babin B. J. and Attaway J. S. (2000). Atmospheric Affect as a Tool for Creating Value md Gaining Share of Customer. Journal of Business Research, 49 (Special Issue), 91-99.
[14] Cottet, P., Lichtlé, M. C., \& Plichon, V. (2006). The role of value in services: A study in a retail environment. Journal of Consumer Marketing, 23(4), 219-227.

[15] Wang, L. C., Baker, J., Wagner, J. A. \& Wakefield, K. (July 2007). Can a retail web site be social? Journal of Marketing, 71(3), 143-157.

[16] Childers, T. L., Carr, C. L., Peck, J. \& Carson, S. 2001. Hedonic and utilitarian motivations for online retail shopping behavior. Journal of Retailing 77(4): 511-535. doi:10.1016/S0022-4359(01)00056-2

[17] Srinivasan, S.S., Anderson, R. and Ponnavolu, K., 2002. Customer loyalty in e-commerce: an exploration of its antecedents and consequences. Journal of retailing, 78(1), pp.41-50.

[18] Mathwick C., Mathota N., and Rigdon E. (2001). Experiential Value: Conceptualization, Measurement and Application in the Catalog and Internet Shopping Environment. Journal of Rerailing, 77,39-56.

[19] Lantieri, T., 2008. Variable Relationships in Online Retailing: Cultivating Consumer Satisfaction and Loyalty. Honors College Theses, p.72.

[20] Hoffman, D.L. and Novak, T.P., 1996. Marketing in hypermedia computer-mediated environments: Conceptual foundations. The Journal of Marketing, pp.50-68.

[21] Keng C., Huang T., Zheng L. \& Hsu M. K. (2007). Modelling service encounters and customer experiential value in retailing. International Journal of Service Industry Management, 18, 349-367.

[22] Park, C. H., \& Kim, Y. G. (2006). The effect of information satisfaction and relational benefit on consumers' online shopping site commitments. Journal of Electronic Commerce in Organizations, 4(1), 70-90.

[23] Kamarul A. (2016). Lazada taps rural market for growth in Malaysia. The Edge Financial Daily. Retrieved on 17th April http://www.theedgemarkets.com/article/lazada-taps-rural-marketgrowth-malaysia

[24] Yudelson, J., \& Yudelson, J. (1999). Adapting McCarthy' s Four P's for the Twenty-First Century. Journal of Marketing Education, 21-60. https://doi.org/10.1177/0273475399211008

[25] Vargo, S. L. \& Lusch, R. F. 2008. Service-dominant logic: Continuing the evolution. Journal of the Academy of Marketing Science 36(1): 110. doi:10.1007/s11747-007-0069-6

[26] Grönroos, C. \& Gummerus, J. 2014. The service revolution and its marketing implications: service logic vs service-dominant logic. Managing Service Quality 24(6): 592-611.

[27] Edvardsson, B., Sandström, S., Kristensson, P., \& Magnusson, P. (2008). Value in use through service experience.

[28] Abd, N., Najafi, B., \& Mohd, F. (2016). Customer Perception of Emotional Labor of Airline Service Employees and Customer Loyalty Intention. The European Proceedings of Social \& Behavioural Sciences EpSBS, (eISSN: 2357-1330). Retrieved from http://dx.doi.org/10.15405/epsbs.2016.08.86 